\title{
Perceptions of Landowners Concerning Conservation, Grazing, Fire, and Eastern Redcedar Management in Tallgrass Prairie
}

\author{
Lois Wright Morton, ${ }^{1}$ Elise Regen, ${ }^{2}$ David M. Engle, ${ }^{3}$ James R. Miller, ${ }^{4}$ and Ryan N. Harr ${ }^{5}$
}

Authors are ${ }^{1}$ Professor and ${ }^{2}$ Graduate Student, Department of Sociology, Iowa State University, Ames, IA 50011, USA; ${ }^{3}$ Regents Professor, Department of Natural Resource Ecology and Management, Oklahoma State University, Stillwater, OK 74078, USA; ${ }^{4}$ Associate Professor, Department of Natural Resources and Environmental Sciences, University of Illinois, Champaign, IL 61801, USA; and ${ }^{5}$ Assistant Scientist, Department of Natural Resources and Ecology Management, Iowa State University, Ames, IA 50011, USA.

\begin{abstract}
Successful prairie restoration will depend in part on convincing private landowners with agricultural and recreational use goals to implement appropriate rangeland management practices, such as prescribed burning and cattle grazing, to control invasive species and encroachment of woody plants. However, landowners have been slow to adopt appropriate practices in the US Midwest. The purpose of this study was to explore attitudes and behaviors of private landowners toward prescribed burning and moderate stocking as rangeland management tools. A survey was mailed to 193 landowners (response rate 51\%) in the Grand River Grasslands region of southern Iowa and northern Missouri. While 68\% of landowners viewed grazing as a legitimate land management tool, only half of landowners thought of fire as a legitimate tool. Over $75 \%$ of respondents believed that the increase in eastern redcedar and other trees in grasslands was a problem, with $44 \%$ considering it a major problem. Although $84 \%$ of landowners said that they had taken action to control eastern redcedar, only $25 \%$ had participated in a prescribed burn. Income from agriculture and recreational goals were negatively and significantly correlated $(-0.252$, $P=0.035$ ). While holding recreational goals constant in the analysis, landowners reporting income from agriculture goals as very or extremely important were negatively and significantly associated with reporting environment and grassland factors as very or extremely important. Adoption of prescribed burning by private landowners might be more widespread if proponents focus on the effectiveness of fire for controlling eastern redcedar, which is viewed as a problem by most landowners in the region. Intervention efforts must include landowners with different goals as part of the promotion and educational process.
\end{abstract}

\section{Resumen}

La restauración exitosa de praderas depende en parte de poder convencer a propietarios de tierras privadas utilizadas con fines agrícolas o de recreación, que implementen prácticas de manejo apropiadas tales como quemas controladas y pastoreo bovino para controlar especies invasoras y la expansión de plantas leñosas. Sin embargo, los propietarios de tierras en la región del Medio-Oeste de los EE.UU. han demostrado lentitud en la adopción de prácticas apropiadas. El propósito de este estudio fue explorar las actitudes y conductas de propietarios de tierras privadas hacia el uso de quemas controladas y pastoreo moderado como herramientas de manejo. Se envió una encuesta por correo a 193 propietarios de tierras (la tasa de respuesta fue del $51 \%$ ) en la región de Grand River Grasslands del sur de Iowa y norte de Missouri. Mientras que 68\% de los propietarios de tierras opinaron que el pastoreo es una herramienta de manejo legítima, solamente la mitad de los propietarios de tierras consideraron el uso del fuego como una herramienta legítima. Más del $75 \%$ de los encuestados manifestaron creer que el aumento de Juniperus virginiana y otros árboles en los pastizales es un problema, y $44 \%$ consideró que este es un problema mayor. Si bien el $84 \%$ de los propietarios de tierras manifestaron haber tomado acción para controlar J. virginiana, sólo el $25 \%$ había participado en una quema prescripta. Los ingresos obtenidos por actividades agrícolas y de recreación exhibieron una correlación negativa significativa $(-0.252, P=0.035)$. Manteniendo las metas de recreación constantes en el análisis, los propietarios de tierras que consideraron sus ingresos agrícolas como muy importantes o extremadamente importantes estuvieron asociados negativa y significativamente con apreciaciones de factores del ambiente y los pastizales como muy importantes o extremadamente importantes. La adopción de quemas controladas por parte de los propietarios de tierras privadas podría ser más generalizada si sus proponentes se enfocaran en el uso del fuego para controlar J. virginiana que es considerada como un problema por la mayoría de los propietarios de tierras de la región. Los esfuerzos de intervención deben incluir propietarios de tierras con diferentes metas como parte del proceso de educación y promoción.

Key Words: adaptive ecosystem management, biodiversity, grazing management, Juniperus virginiana, landowner attitudes, prairie restoration, prescribed burning

This work was supported by the Leopold Center for Sustainable Agriculture at lowa State University.

Correspondence: Lois Wright Morton, Department of Sociology, lowa State University, 317C East Hall, Ames, IA 50011, USA. Email: Iwmorton@iastate.edu

Manuscript received 8 April 2009; manuscript accepted 27 June 2010.

\section{INTRODUCTION}

The majority of grassland habitats remaining in the tallgrass prairie ecoregion consist of privately held pastures and hayfields, which have declined in area over the past several decades (Stephens et al. 2008; Fargione et al. 2009). Of 
particular interest are the relatively small and isolated grassland reserves and remnant prairies on the eastern fringe of the tallgrass region, such as Iowa and Missouri, embedded in landscapes with sizable parcels of private working grasslands used primarily for grazing and recreation. In these landscapes, fire and grazing can be an integrator of biotic and abiotic as well as social and economic variables (Engle and Bidwell 2000; Curtin 2007). However, this integration can occur only if private landowners understand complementary land use goals, grassland ecosystem function, and the management of grazing and fire. Conservation management must be a collective, public agenda if woody plant encroachment is to be controlled, biodiversity increased, and grassland ecosystem resilience achieved (Walker and Salt 2006). Setting a public grassland agenda on private lands requires some level of shared values about the importance of the grasslands and recognition that current conditions are a "public problem" requiring individual and collective actions (Wood and Doan 2003).

Widespread conversion of tallgrass prairie to cropland has fragmented the landscape, undermined the central role of fire and grazing as a natural disturbance in remnant grasslands, and resulted in these grasslands managed with agronomic practices rather than ecological principles (Engle and Bidwell 2000). Combined with heavy stocking of domestic livestock that reduce fuel and fire intensity (Briggs et al. 2005), woody plants, particularly fire-intolerant eastern redcedar (Juniperus virginiana L.), are rapidly displacing the remaining grassland in the central United States (Briggs et al. 2002; Coppedge et al. 2002; Engle et al. 2008). The Flint Hills, where most private grasslands are burned annually, is a notable exception.

Because of the dominance of privately owned land in the central United States, successful maintenance and restoration of grass landscapes depend on private landowners adopting appropriate fire and grazing practices to control encroachment of eastern redcedar and other invasive species. Based on a dismal record of maintaining open grassland landscapes (e.g., Engle et al. 2008), extension and technical assistance agencies lack the knowledge base necessary to educate and convince private landowners to apply these practices. Convincing landowners to practice effective management and restoration strategies is predicated on their understanding and valuing grassland ecosystems and how they think about production goals compared to environmental goals.

A key barrier to public recognition of a grassland region being at risk and needing collective action is the capacity for finding common ground among private landowners with diverse goals and land uses. Regions with a mix of established agricultural lands and properties acquired for recreational purposes often have competing financial versus nonmonetary motivations driving land use decisions (Koontz 2001). Over $50 \%$ of respondents of the 2009 Iowa Farm and Rural Life Poll agree or strongly agree that conversion of pastureland in Iowa to recreational and hunting land has reduced available pasture for grazing (Arbuckle et al. 2009). The conflict between recreational and agricultural uses of western public grazing lands has been documented by Wulfhorst et al. (2006) and others. Strategies to arrest additional grassland loss and rebuild the regional ecosystem through landscape-scale restoration require a management framework that integrates public reserves and private working lands (Kreuter et al. 2008).
Mission-driven government agencies and private landowners with environmental preferences are frequently viewed with distrust and skepticism by agricultural producers (Morton 2008; Moore et al. 2008). Yet if grassland conservation practices are to be widely implemented, both agricultural producers and recreational landowners must find some value in grassland wildlife, wildlife habitat, and controlling plants that displace native grassland species.

Scientific knowledge about the grassland ecosystem and fire and grazing relationships must be integrated with local knowledge and values of ranchers managing for production goals as well as recreational landowners. The explicit integration of local landowner beliefs and values and their understanding of the ecosystem within which rangeland decisions are made are necessary for successful ecosystem management (Curtin 2007). A first step in the effective engagement of private landowners in grassland conservation and adoption of fire and grazing management tools is an understanding of their current land use goals, perceptions of the importance of grassland, and opinions about fire and grazing management as acceptable practices.

In this article, we report results of an exploratory survey of landowners in the Grand River Grasslands of northern Missouri and southern Iowa that will support future development of intervention strategies to actively involve landowners in adaptive experiments involving fire and grazing on their own lands. While research has been conducted on perceptions of fire and grazing on public rangelands in the western United States (e.g., Brunson and Evans 2005) and in private-land states such as Texas (e.g., Kreuter et al. 2008), little is known about landowner perceptions in the tallgrass prairie region of the midwestern United States, where grassland is more fragmented by cropland than in arid and semiarid rangeland regions. Hence, our overarching research question was, "To what extent do landowners in the region value their grasslands and the wildlife species and habitats that are unique to the tallgrass prairie?" The degree of importance that landowners place on their grasslands and its attributes provide insight into whether there is substantive social support and the potential to build a public agenda of grassland restoration on private lands. Subsets of this question involve land management goals, concern about woody plant encroachment, and the use of prescribed fire as a management tool. We posit that those landowners who report income from agriculture as a very important factor in land management decisions will have different orientations toward grassland restoration than those who manage their lands for recreation purposes.

\section{METHODS}

A landowner survey administered in the fall of 2007 in the Grand River Grasslands region provided baseline data on landowners' current land use practices, including livestock grazing and control of invasive species, perceptions of eastern redcedar encroachment, and fire and grazing management. Additional items asked landowners to report on the importance of grassland species, wildlife habitat, and grassland restoration as environmental concerns. The Grand River Grasslands, embedded within an extensive region of mixed land cover 
types that includes substantial amounts of grassland, encompasses 28328 ha in Ringgold County, Iowa, and Harrison County, Missouri, most of which is privately owned and used primarily for cattle farming and recreation. This is a priority conservation area because it represents one of the few grassland-dominated landscapes in the Central Tallgrass Prairie Ecoregion (Missouri Department of Conservation 2005; The Nature Conservancy 2008b). About 4500 ha of the region are under conservation management by nonprofit and public agencies (R. Harr, personal communication, January 2009).

Surveys were mailed to the full population of 193 landowners with parcels of approximately 8 ha or larger in the Grand River Grasslands. These individuals were identified by plat maps, USDA-NRCS staff, the Iowa State University Cooperative Extension, and Missouri and Iowa state wildlife biologists as owning lands within the region. Dillman's (2000) multiplecontact survey methodology was used: 1) a "survey is coming" color picture postcard mailed on day $1 ; 2$ ) a cover letter and survey questionnaire on day $7 ; 3$ ) a reminder color postcard mailed on day 16 to nonrespondents, and 4) a cover letter with a replacement questionnaire to nonrespondents on day 24 . The Iowa State University Office of Research Assurance reviewed and accepted the proposed survey methodology and instruments in protection of human subjects. Twenty-seven landowner contacts were invalid addresses or duplicate landowners. The number of completed surveys returned was 85 , yielding a response rate of $51 \%$.

Previous landowner surveys conducted on other US rangelands (Brunson and Shindler 2004; Kreuter et al. 2004; Brunson and Evans 2005; Olenick et al. 2005) were used to develop survey items. Natural resource agency personnel and local environmental and farming nonprofit groups reviewed the final survey for relevance to privately owned grassland in the Midwest. The final questionnaire consisted of 37 closed-ended questions that used categorical and Likert response scales. For the latter, respondents were asked to rate items on a five-point scale as 1) not important, 2) somewhat important, 3) no opinion, 4) very important, or 5) extremely important. The survey instrument was revised after pilot testing in a similar, nearby region with landowners who raise cattle.

Our exploratory work focuses on associations among variables rather than causal models, which are not hypothesized. Analyses of relationships among variables (direction and strength) will provide guidance for future development of theory-driven causal models that can be used to test and evaluate landowner interventions. Frequency percentages are reported to show the distribution of respondent answers. Partial correlations allow us to explore the associations between landowner perceptions of tallgrass prairie and management with income from agriculture while controlling for recreational goals. In correlation analyses, the five-point importance scale was recoded to omit the "no opinion" response. Management goals, relating either to income from agriculture or to recreation (hunting/fishing), were measured on a four-point scale from $1=$ not important to $4=$ extremely important. Environmental and grassland factors were evaluated for their association with these two management goals. The natural resource use-environmental protection continuum representing general environmental values was measured on a 10-point scale where 1 emphasizes extreme functional and economic considerations and 10 emphasizes extreme environmental protection. Grassland factors (protecting wildlife habitat, biodiversity, restoring prairies/grasslands, pheasant/ quail/turkey, deer, butterflies, wildflowers/native plants, prairie chickens, and controlling invasive species) were measured on a four-point scale from $1=$ not important to $4=$ extremely important.

"Eastern redcedar is a problem" measured landowner perceptions of whether the increase in eastern redcedar is a minor or major problem (1) or no problem (0). Those landowners who viewed eastern redcedar as a problem could report the reasons, marking loss of forage and loss of wildlife habitat as yes (1) or no (0). Fire and grazing as legitimate tools measured whether landowners perceived they are legitimate land management practices (1) or an unnecessary practice, to be done infrequently, or to be avoided because of negative impacts (0). The rationale for grouping these three responses into the 0 category was that these two practices are not likely to be used if not considered legitimate by landowners. Landowners reporting they were "not sure" (1) about the legitimacy of these practices were compared to all other responses $(0)$ to identify if lack of knowledge or uncertainty about the practice was associated with income from agriculture or recreational goals. Concern about loss of forage and loss of wildlife habitat as an effect of prescribed burns was measured on a four-point scale from $1=$ not a concern to $4=$ great concern.

Pearson correlations were first used to analyze the relationship between income from agriculture and recreation goals. This was followed by computing partial correlations of income from agriculture with grassland factors and management practices while controlling for recreation goals. These coefficients indicate the direction (positive or negative) and strength (size of coefficient) of the association between two variables with significance indicated at the $P<0.05$ or $P<0.01$ level. Income from agriculture and income from recreation were not mutually exclusive categories; that is, respondents rated both variables according to perceptions of importance, thus the need to hold recreation constant in our analyses. The Statistical Package for the Social Sciences and the Dimensions software program were used for data management and analyses.

\section{RESULTS}

Almost $80 \%$ of respondents reported the primary use of their property as some combination of crop and livestock production, and a quarter reported that they incorporate wildlife into their ranching operations (i.e., a mixed livestock and wildlife ranch or mainly a wildlife operation). About three-quarters grazed livestock, mostly beef cattle. Nearly $60 \%$ of landowners reported that they have lived in or owned land in Ringgold County, Iowa, or Harrison County, Missouri, for more than $25 \mathrm{yr}$, or longer than one generation, while $8 \%$ have owned land there less than $5 \mathrm{yr}$. The average ownership was $183 \mathrm{ha}$, ranging from 16 ha to 1315 ha. Forty-eight percent of landowners currently live on their land. Of those who did not reside on their land, $54 \%$ live less than $80 \mathrm{~km}$ away, $11 \%$ live 80-161 km away, and 35\% live more than $161 \mathrm{~km}$ away. About half the landowners received $25 \%$ or less of their annual 
Table 1. Mean rank of importance and correlation between the importance that landowners place on natural resource use and attributes of grasslands when making land management decisions based on agriculture goals while controlling for recreation goals (see text for rating scales).

\begin{tabular}{|c|c|c|}
\hline & Rank importance & $\begin{array}{l}\text { Income from agriculture } \\
\text { correlations }\end{array}$ \\
\hline & Mean (SD) & Coefficient ( $P$ value $)$ \\
\hline Income from agriculture & $3.227(0.873)$ & \\
\hline Recreation (control) & $2.394(0.943)$ & $-0.252(P=0.035)$ \\
\hline \multicolumn{3}{|l|}{ Environmental and ecosystem attributes } \\
\hline Natural resource use & $6.274(1.484)$ & $-0.289(P=0.024)$ \\
\hline Protecting wildlife habitat & $2.939(0.802)$ & $-0.301(P=0.015)$ \\
\hline Biodiversity & $2.767(0.972)$ & $-0.075(P=0.636)$ \\
\hline Restoring prairies/grasslands & $2.673(0.963)$ & $-0.286(P=0.036)$ \\
\hline Pheasant, quail, turkey & $3.000(0.761)$ & $-0.295(P=0.014)$ \\
\hline Deer & $2.439(1.039)$ & $-0.360(P=0.003)$ \\
\hline Butterflies & $2.729(0.906)$ & $-0.245(P=0.064)$ \\
\hline Wildflowers/native plants & $2.803(0.909)$ & $-0.223(P=0.087)$ \\
\hline Prairie chickens & $2.593(0.949)$ & $-0.105(P=0.431)$ \\
\hline \multicolumn{3}{|l|}{ Grassland management } \\
\hline Controlling invasive plants & $3.328(0.644)$ & $-0.022(P=0.866)$ \\
\hline Redcedar is a problem & $0.788(0.412)$ & $0.142(P=0.259)$ \\
\hline Loss of forage due to redcedar & $0.386(0.490)$ & $0.237(P=0.050)$ \\
\hline $\begin{array}{l}\text { Loss of wildlife habitat due to } \\
\text { redcedar }\end{array}$ & $0.200(0.403)$ & $0.006(P=0.962)$ \\
\hline Fire is a legitimate tool & $0.699(0.463)$ & $-0.303(P=0.030)$ \\
\hline Not sure if fire is legitimate tool & $0.232(0.425)$ & $-0.029(P=0.817)$ \\
\hline Loss of forage due to fire & $0.373(0.488)$ & $0.151(P=0.257)$ \\
\hline Loss of wildlife habitat due to fire & $2.525(1.058)$ & $0.117(P=0.374)$ \\
\hline Grazing is a legitimate tool & $0.875(0.334)$ & $0.036(P=0.795)$ \\
\hline Not sure if grazing legitimate tool & $0.176(0.384)$ & $0.025(P=0.841)$ \\
\hline
\end{tabular}

household income from their land, while $29 \%$ of landowners received more than half their income from their land.

\section{How Important Are Environmental and Grassland Ecosystem Attributes?}

Landowner respondents located themselves, on average, close to the middle of the natural resource use-environmental protection continuum $($ mean $=6.274 ; \mathrm{SD}=1.484$; Table 1$)$. Less than $8 \%$ of respondents were more than one standard deviation below the mean, giving priority to natural resource use rather than protection. Reducing soil erosion and controlling invasive species were the most highly rated environmental issues, with $95 \%$ and $86 \%$, respectively, reporting these issues as very or extremely important (Fig. 1). Protecting wildlife habitat and enhancing watersheds were of lesser importance, but these issues were still rated as either very or extremely important by about $70 \%$ of respondents. In contrast, $46 \%$ rated increasing biodiversity as either very or extremely important, and almost a third of the survey respondents had "no opinion" about biodiversity. The importance of restoring prairies and grasslands (51\% very/extremely important) was rated a little higher than increasing biodiversity but with fewer "no opinions" (17\%).
Landowners were also asked how important it was to them that certain wildlife species were present on their land: pheasant (Phasianus colchicus), quail (Colinus virginianus), and turkey (Meleagris gallopavo silvestris). These game bird species were valued highly by landowners, with $80 \%$ reporting that having these species on their land was either very important or extremely important. The percentage of respondents rating other grassland species as very or extremely important was much lower: songbirds (62\%), wildflowers/ native plants $(55 \%)$, white-tailed deer (Odocoileus virginianus; $54 \%$ ), and greater prairie-chicken (Tympanuchus cupido; $48 \%$ ). In general about $11-13 \%$ reported not having an opinion on these species with the exception of white-tailed deer (about 5\% had "no opinion"). It is worth noting that whitetailed deer were ranked not important by $20 \%$ of respondents, the highest percentage for any species in this response category.

\section{Grazing}

Grazing was a common and highly regarded land use in the Grand River Grasslands. Seventy-two percent of landowners grazed livestock with an average of 126 head of mature livestock (cattle) per owner (range: 4-850 head). Pastures in the Grand River Grasslands were grazed an average of 9 mo per year (range: 5 mo to year-round). Rotational grazing was practiced by almost $69 \%$ and continuous grazing by nearly $28 \%$. Landowners who grazed pastures with livestock also reported incorporating other grazing management practices, including reduced stocking rates $(18 \%)$, seasonal or yearlong rest from grazing $(12 \%)$, and management-intensive grazing $(10 \%)$. Fifty-percent of those who grazed cattle reported balancing forage production with forage demand when determining the appropriate stocking rate. Over $40 \%$ determined stocking rates based on the number of livestock they have, while others reported factors such as livestock performance $(33 \%)$, economics $(24 \%)$, and wildlife habitat requirements $(17 \%)$. Fifty-two percent provided supplemental feed/ forage to livestock on pasture. Grazing was perceived as a legitimate land use by $68 \%$ of all landowners, with only $4 \%$ viewing it as an unecessary practice and $21 \%$ unsure.

\section{Eastern Redcedar Abundance and Management}

About one-fifth of landowners estimated that eastern redcedar is moderately or extremely abundant on their own lands. Almost $79 \%$ said that most of their lands are open pasture or grassland. The majority of landowners considered the increase in eastern redcedar and other trees in grasslands as a problem with $44 \%$ classifying it as major and $32 \%$ as a minor problem. Sixteen percent were not sure if it was a problem, while $7 \%$ did not think the increase in woody species was a problem. Of those who thought eastern redcedar increase was a problem, the majority $(81 \%)$ of landowners cited the loss of grassland as the primary reason it was a problem. Loss of forage was reported as the second most important reason (39\%), followed by loss of wildlife habitat $(20 \%)$.

More than $84 \%$ of all landowner respondents had regularly or occasionally taken action to control eastern redcedar and other trees in their pastures or grasslands. Manual and mechanical treatments were by far the most common control methods with $75 \%$ reporting hand removal, $59 \%$ mowing, and 


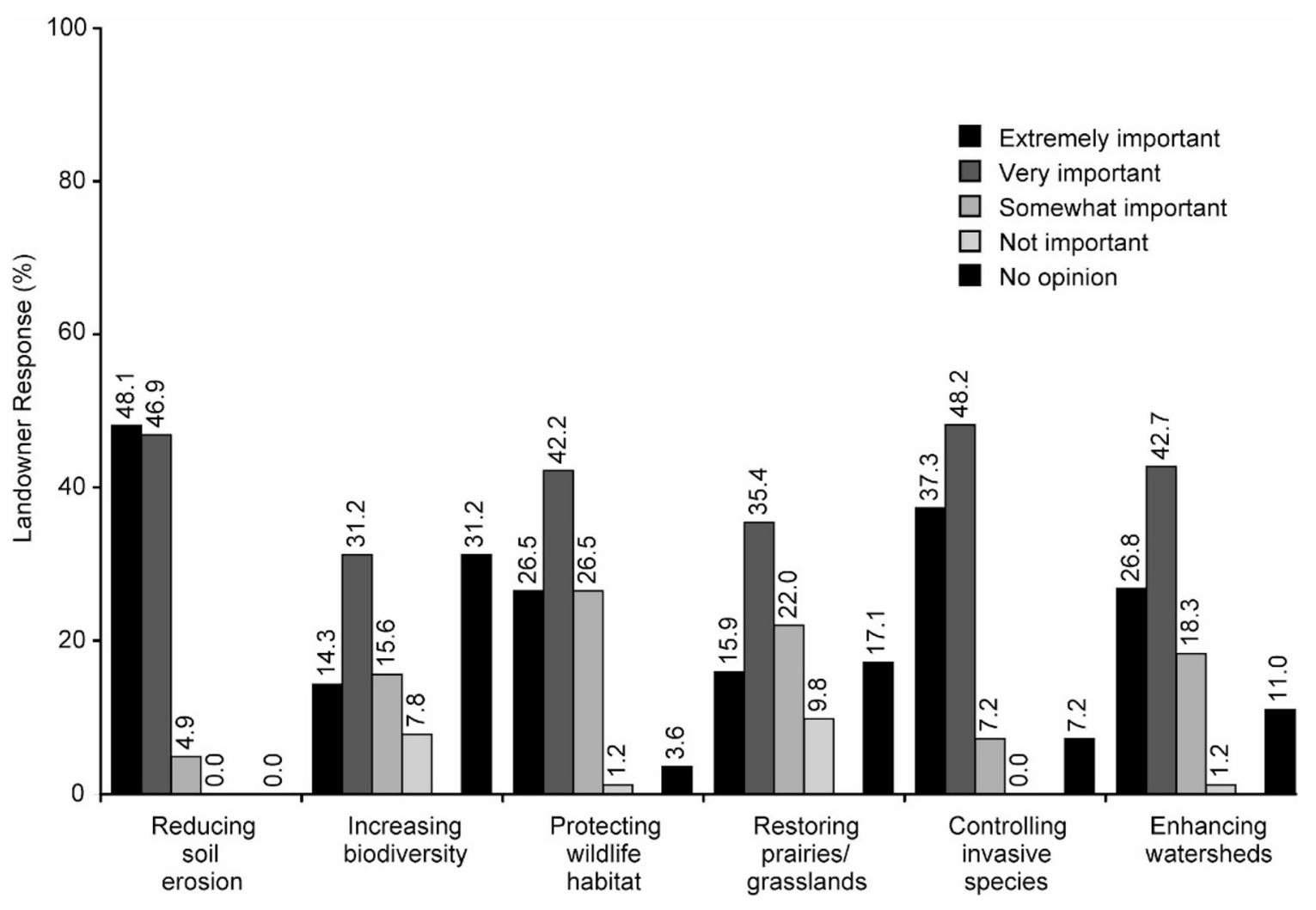

Figure 1. Proportion (\%) of responses of landowners in the Grand River Grasslands to the question "How important to you are each of these environmental issues?"

$30 \%$ bulldozing. Less than $16 \%$ had used prescribed burns to control eastern redcedar. Congruent with stated practice, mechanical removal dominated the list of acceptable practices for local control of eastern redcedar (Fig. 2). More landowners had used herbicides than prescribed burning, but prescribed burning (34\% strongly supportive) had stronger support than herbicides (20\% strongly supportive; Fig. 2).

About a third of landowners expressed "no opinion" about the acceptability of prescribed burning, and $40 \%$ had "no opinion" on the formation of burning cooperatives to control eastern redcedar. Although $63 \%$ of respondents were strongly or somewhat supportive of using herbicides to control eastern redcedar, more landowners $(12 \%)$ were strongly opposed to using herbicides than those strongly opposed to mechanical removal $(1 \%)$, prescribed burning $(6 \%)$, or formation of burning cooperatives $(7 \%)$. Seventy-three percent of landowners said they have incurred costs over the past $5 \mathrm{yr}$ in controlling eastern redcedar, with $14 \%$ incurring major costs and $59 \%$ incurring minimal costs.

\section{Prescribed Burning}

Prescribed burning was not commonly practiced or well understood by landowners in the Grand River Grasslands. Only $25 \%$ of landowners had participated in a prescribed burn on a pasture or grassland, and about $5 \%$ reported that they did not know what prescribed burn means. More than $51 \%$ of all landowner respondents regarded prescribed burning as a legitimate land management tool. Eleven percent thought it was an unnecessary practice, and $26 \%$ reported being unsure whether it was a legitimate practice. Landowners perceived the greatest risks associated with prescribed burning to be liability and damage to private property (Fig. 3). Liability was a moderate to great concern for $68 \%$ of landowners, followed by damage to private property $(55 \%)$ and loss of wildlife habitat $(47 \%)$. Harm to wildlife $(45 \%)$, loss of wildlife habitat $(47 \%)$, soil erosion $(46 \%)$, and smoke $(43 \%)$ were of moderate or great concern to less than half the respondents. More than one-third of landowners perceived loss of forage, smoke, and reduced scenic quality to not be a concern. Less than $10 \%$ reported that they did not know if prescribed burns harm wildlife, are a concern to liability, damage private property, result in loss of wildlife habitat, increase soil erosion, are a risk to human safety, cause loss of forage, affect smoke levels, or reduce scenic quality.

\section{Grassland Management}

Almost $94 \%$ of the landowner respondents rated being a good steward of the land as very or extremely important in their land management decisions. There was much less consensus among landowners as to the importance of other goals driving their management decisions. Two of the major land uses in this region are agriculture and recreation. Income from agriculture was perceived by landowners to be very important (mean $=3.227 ; \mathrm{SD}=0.873$ ), and recreation was perceived by landowners to be somewhat important (mean $=2.394$; $\mathrm{SD}=0.943$; Table 1). Eighty-one percent reported that income from agriculture was very or extremely important to them in making land management decisions with about $18 \%$ saying that it was somewhat or not important. Slightly more than $46 \%$ said that recreation (hunting/fishing) was a very or 


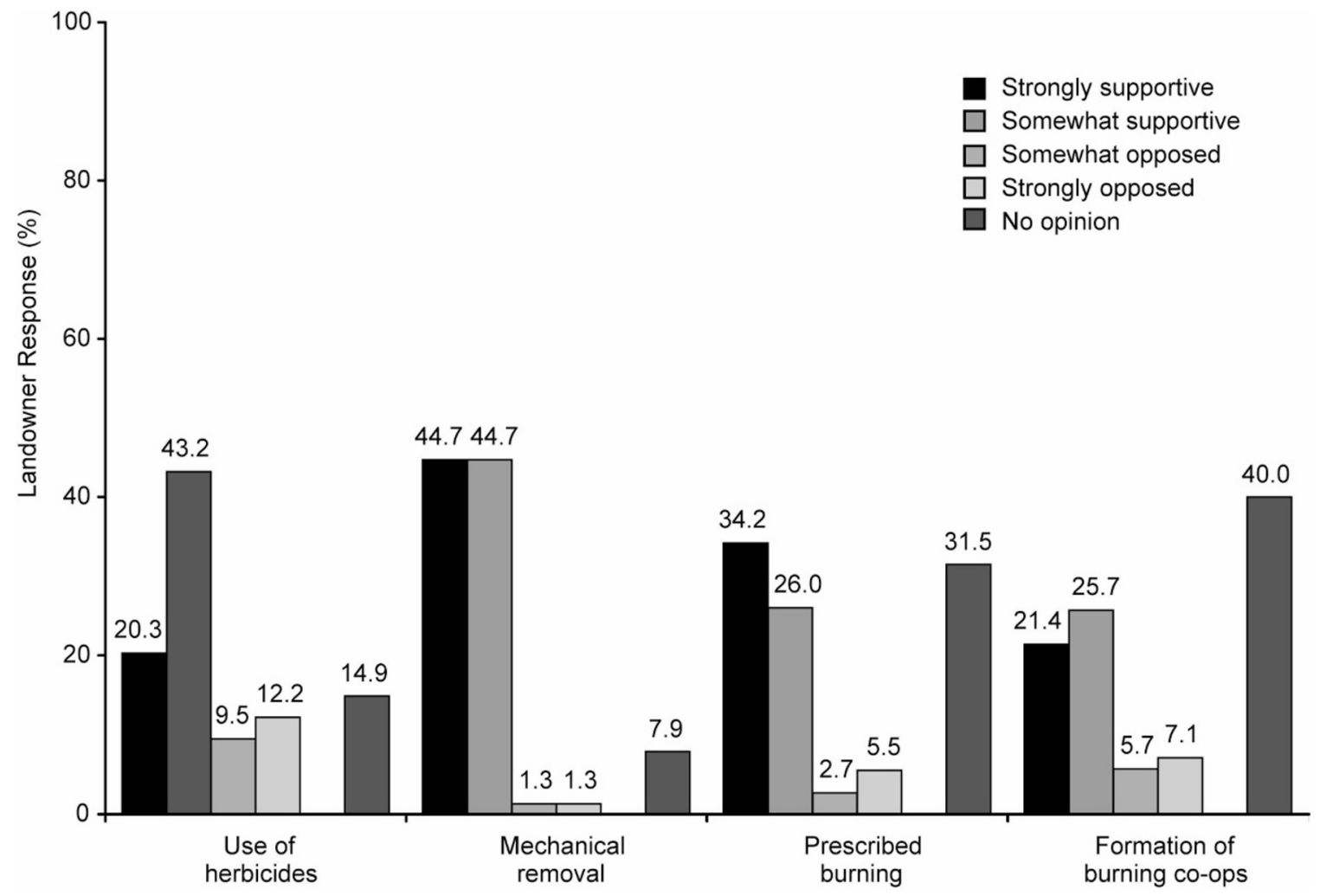

Figure 2. Proportion (\%) of responses of landowners in the Grand River Grasslands to the question "How would you feel about the following taking place locally to control redcedar?"

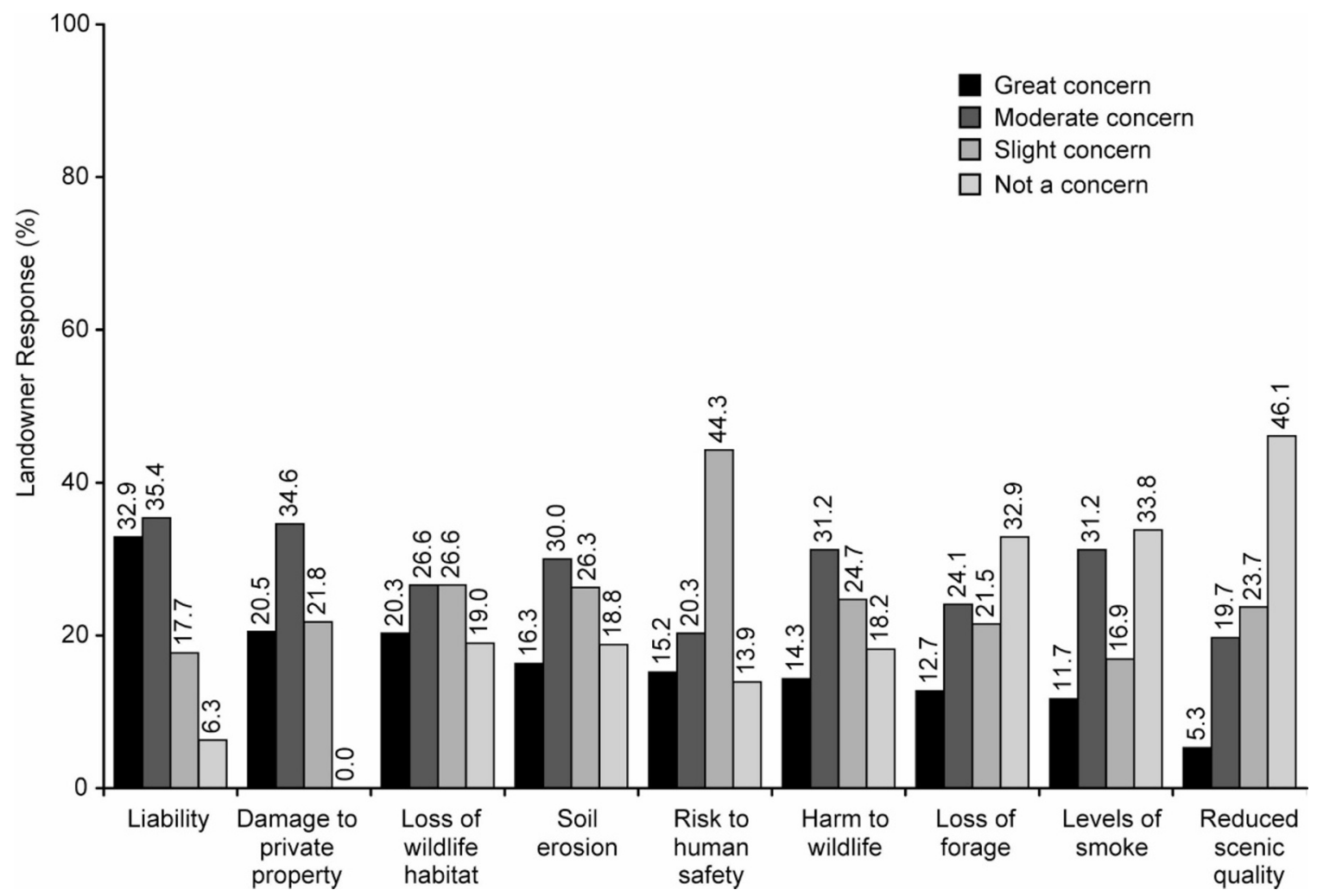

Figure 3. Proportion (\%) of responses of landowners in the Grand River Grasslands to the question "How concerned are you about the following possible effects of local prescribed burns?" 
extremely important factor when deciding how to manage their land; $50 \%$ reported it somewhat or not important. A significant and negative correlation (Pearson) between these two goals $(P>0.05)$ suggests that these goals may be associated with distinct differences in perspectives on environmental and grassland ecosystem attributes and management practices.

When recreation goals were held constant, income from agriculture was negatively and significantly associated with many of the environment and grassland ecosystem attributes: natural resource use-environmental protection continuum $(P<0.05)$; protecting wildlife habitat $(P<0.01)$; restoring prairies/grasslands $(P<0.05)$; pheasant, quail, and turkey $(P<0.01)$; deer $(P<0.01)$; butterflies $(P<0.10)$; and wildflowers/native plants $(P<0.10)$. The negative relationship with agriculture goals can be interpreted as the more important income from agriculture was to the respondent, the more likely that natural resource use had a higher priority than environmental protection. When holding agricultural goals constant, the relationship was positive between those who manage for recreation goals and environmental protection. Significant grassland factors can be interpreted as the more important income from agriculture was to the respondent, the less likely the respondent rated the group of environmental and grassland ecosystem attributes (i.e., protecting wildlife habitat; restoring prairies/grasslands; pheasant, quail, and turkey; deer; butterflies; and wildflowers/native plants) as very or extremely important.

The second portion of Table 1, "Grassland Management," examined the relationship between income from agriculture while controlling for recreation goals and grassland management concerns and practices. Four factors deal with invasive plants and encroachment of eastern redcedar. Only one of these factors, loss of forage due to redcedar $(P<0.05)$, was significantly associated with managing for income from agriculture. The more important income from agriculture, the more likely loss of forage from redcedar was viewed as a problem. There were no significant associations between income from agriculture and perceptions that eastern redcedar was a problem, controlling invasive plants was very or extremely important, or loss of wildlife habitat due to eastern redcedar was a problem.

Prescribed fire and grazing are two practices used to manage grasslands. Prescribed fire as a legitimate tool was negatively $(P<0.05)$ associated with managing for income from agriculture. This is interpreted as the more importance assigned to income from agriculture by the landowner, the less likely prescribed fire was considered a legitimate practice when controlling for recreation goals. Responses of "not sure that fire is a legitimate tool," "loss of forage due to prescribed burns," and "loss of wildlife habitat due to prescribed burns" were not significantly associated with income from agriculture. Further, "grazing as a legitimate tool" and "not sure if grazing is a legitimate tool" were not significantly associated with managing for income from agriculture net of recreation.

\section{DISCUSSION}

Landowner Attitudes and Perceptions Related to Conservation The Grand River Grasslands is dominated by rolling hills and incised waterways. Our survey results indicate that landowners have learned the importance of reducing soil erosion and enhancing watersheds and are aware of the threat posed by invasive species. Nevertheless, their perceptions and attitudes toward other conservation issues, such as biodiversity protection, were much less evident. Although all respondents had opinions about the importance of reducing soil erosion, many reported "no opinion" on other grassland factors, suggesting that a sizable number of landowners may lack knowledge about the grassland ecosystem. Responses of "no opinion" in closed-end surveys have been shown to be associated with a lack of knowledge or interest (Rossi et al. 1983). The combination of "no opinion" and "not important" responses seems to indicate that a considerable number of landowners are not engaged in the concept or practice of restoring prairies and grasslands.

The most highly rated factors, reducing soil erosion and controlling invasive species, are likely the result of technical agency investment in agricultural technology transfer and financial incentives to prevent declines in productivity (Walker 1982; Anderson 1996; Pimentel et al. 2000; Triplett and Dick 2008). Erosion and invasive species (i.e., noxious weeds) in cropland environments are deemed socially unacceptable in many communities to the extent that local, state, and federal governments regulate and provide cost-sharing incentives to manage these issues in regions where crop production is an important industry (Skinner et al. 2000; Sabatier et al. 2005; Morton 2008).

Lessons learned from the Dust Bowl of the 1930s (when extreme soil loss occurred), as well as the floods of 1913 and 1927 and the more recent floods in 2008, have led to systematic efforts including Farm Bill economic incentives and Environmental Protection Agency regulations that focus landowner attention on erosion issues and soil conservation practices (Sabatier et al. 2005; Kline 2007; Anderson-Wilk 2008). Landowners with strong agricultural goals seem less motivated to manage for environmental conditions, prairie restoration, and wildlife. With better than a half century focused on highinput production agriculture by cooperative extension and other agencies that includes managing for reduced soil erosion and weeds (Edwards 1989; Sabatier et al. 2005; Kline 2007), other conservation concerns have much ground to make up to achieve similar levels of landowner acceptance. Further evidence of this disparity lies in landowner attitudes toward wildlife. Game bird species were rated as highly valued by landowners. In contrast, landowners expressed the lowest value for the greater prairie-chicken, at one time an important game species but now a species of conservation concern that is actively managed for on reserves and under various incentive and public-private partner programs in the Grand River Grasslands (Zohrer 2005; The Nature Conservancy 2008a).

Landowner goals influence landowner management decisions. The challenge for natural resource professionals is to convince agricultural landowners that wildlife habitat and environmental protection can be integrated with agricultural production goals. Collectively, these results indicate a general lack of understanding among landowners regarding habitat requirements of animal species native to tallgrass prairie as well as the threat posed by woody species to these species over relatively short time frames (Engle et al. 2008). Further, many landowners appear to perceive the grasslands as a productive 
resource but do not recognize the full range of ecosystem services they also provide. These may be viewed as competing goals, but there also seems to be some evidence that awareness of nonagricultural ecosystem services is simply low to nonexistent. These knowledge gaps represent significant opportunities for educating both agriculture and recreational landowner groups.

Although many landowners reported valuing both recreational and agricultural uses of their land, land management decisions appear to vary on the basis of which use landowners view as most important. The negative correlations between income from agriculture and the importance assigned to grassland restoration and wildlife species suggest that motivating changes in grassland management practices based on environmental values alone is likely to be insufficient for those whose livelihoods depend on agriculture. Landowners who place a high value on recreational uses tend to place a high value on wildlife habitat, grassland restoration, and native species on their own lands. We therefore suspect that recreational-use landowners will more likely be open to receiving information about grassland ecology and accept guidance on fire and grazing practices that restore grassland and native species. The challenge will be to help both groups find common ground in developing a public agenda to protect the grasslands while ensuring that income from agricultural uses is not placed at risk.

\section{Fire and Grazing}

Attitudes toward fire and grazing as land management practices reflect trends that are useful for identifying the barriers to landowner adoption of appropriate prescribed burning and grazing management practices. While grazing was accepted as a legitimate land management practice by most of the landowners, a much lower percent perceived prescribed burning to be a legitimate tool. The reason for this disparity may be related to the limited firsthand experience these landowners have with fire. Few have participated in a prescribed burn, and even fewer have burned to control eastern redcedar on their own land. Eastern redcedar encroachment is generally recognized as a problem, but a substantial number of landowners have not yet recognized prescribed burning as an appropriate or effective management tool. This conclusion is underscored by the fact that more than $25 \%$ of our respondents reported that they were uncertain about whether fire is a legitimate tool. This suggests that landowners need opportunities to learn more about the impact of fire on grassland, learn the mechanics of conducting a prescribed burn, and generally acquire experience with prescribed fire.

Aspects of prescribed burning of greatest concern to landowners were liability, damage to private property, and loss of wildlife habitat, which may be reasonable concerns for those unfamiliar with rangeland prescribed burning. Kreuter et al. (2008) found that reducing liability was the factor most likely to encourage use of fire. To alleviate these concerns, educators have access to an abundance of materials to inform landowners of approaches to managing liability, including prescribed burning associations (e.g., Taylor 2005; Weir and Bidwell 2005) and planning and preparation for prescribed fire that will minimize the risk of escaped fire while accomplishing objectives of the burn (e.g., Higgins et al. 1989; Bidwell et al. 2006). Demonstrating prescribed burning and favorable livestock and wildlife habitat response, an approach proven to increase landowner acceptance of fire (Taylor 2005), should increase landowner comfort with and eventual adoption of this practice.

Given the lack of experience with prescribed burning, it follows that landowners in the Grand River Grasslands would prefer mechanical treatments for controlling eastern redcedar. The majority of respondents acknowledged that the increase in eastern redcedar and other trees is a problem, so creating awareness of the cost-effectiveness and overall efficacy of fire compared to mechanical removal (Ortmann et al. 1998) would also improve landowner adoption of prescribed burning. Respondents reported that they are more likely to incur minor rather than major costs in controlling redcedar, and this suggests that the problem may not yet be identified as critical and in need of a solution. Thus, the most important point may be that landowners should be educated as to the value of controlling encroachment early because restoration of grassland from the woodland stage is cost prohibitive (Engle and Stritzke 1992; Ansley and Rasmussen 2005).

Perhaps the greatest practical barrier to the effective use of prescribed burns for controlling eastern redcedar and other encroaching woody plants is the regional tradition of heavy grazing (Briggs et al. 2005). Most cattle in Iowa are owned in small herds that are not generally profitable but are nevertheless maintained because grazing is but one enterprise on multienterprise farms (Miller et al. 2001). Because feed costs are the single greatest variable explaining profitability across cow herds (Miller et al. 2001), one might deduce that balancing cow numbers with forage production would be a first step to reducing input costs and to increasing profitability of the cowcalf enterprise in the Grand River Grasslands. Even though half the livestock grazers reported that they balance forage supply with forage demand, $40 \%$ based their stocking rate on the number of animals owned, and over half supplement (i.e., substitute) pasture forage with harvested feeds. Moreover, less than one-fifth of owners stock at a reduced rate even though this region regularly experiences forage-limiting seasonal droughts (Cleaveland and Duvick 1992; Woodhouse and Overpeck 1998). These results suggest that, for many landowners who lack a profit motive, maintaining ownership of stock numbers is a higher-order personal preference than restoring grassland habitats.

Our results are comparable to other studies that have examined attitudes toward prescribed burning, grazing, and the acceptability of various plant control treatments. Brunson and Shindler (2004), exploring geographic variation in acceptability of fuel treatment options in the western United States, found that mechanical methods were preferred over prescribed burning in all study locations. Because Brunson and Shindler (2004) surveyed the general public rather than focusing exclusively on rangeland owners, their results apply to a different demographic group, and their study was motivated by the influence of public opinion on land management in public lands states of the western United States. However, convergence of these two studies suggests the significant challenge ahead to convey the ecological advantage of burning over mechanical methods while calming public 
anxiety over prescribed burning, a tool useful for reducing wildfire risk with benefits to the general public (Yoder et al. 2004; Yoder 2008).

In conclusion, our exploratory study has revealed apparent disjunctions in the way landowners think about certain issues related to prairie and grassland restoration and management. Landowners identified control of invasive species as a major issue, but they ascribed less importance to restoring prairie and grassland that are subject to species invasions, which can cause loss of prairie and grassland. In particular, most respondents viewed the increase in eastern redcedar and other trees as a problem primarily because tree encroachment causes loss of agriculturally productive grassland. Most landowners also believed that protecting wildlife habitat is very important and value grassland-dependent species on their properties yet did not seem to recognize the appropriate management tools to achieve this goal. This suggests that they are thinking about their own parcel's productivity potential but have little vision of the grasslands as a unified ecosystem. Because landowners in the Grand River Grasslands recognize the importance of reducing soil erosion, controlling invasive species, protecting wildlife habitat, and enhancing watersheds, the connection needs to be established as to how these ecosystem services can be provided through restoration of local prairie.

Although our findings reflect only the perceptions of private landowners in the Grand River Grasslands, a small portion of the former tallgrass prairie ecoregion, they offer insights into the influence of agricultural and recreational goals on management practices in regions where most grassland is privately owned. Distinct differences in landowner goals and perceptions of prairie strongly suggest that educational messages be tailored differently for different audiences to motivate effectively.

\section{IMPLICATIONS}

Restoring prairie landscapes fragmented by cropland and trees presents a complex and difficult challenge when lands are held under private ownership in small parcels with contrasting goals related to production agriculture and recreational use of land. Koontz (2001) notes that financial versus nonmonetary motivations in land use decisions have critical environmental and social consequences. Effective prairie restoration must integrate the science of fire and grazing with human understanding and perceptions of grassland ecosystems. "Producers rarely see a strong link between the provision of ecological services and the revenues they receive from farming" (Batie 2009, p. 384). This survey of Grand River Grassland landowners shows us where to start in the building of a public agenda that links science to the social context of landowners within the historical tallgrass prairie region. This agenda requires public definition of the grassland at risk (e.g., there is a problem) and collective willingness to undertake management actions on private lands to protect it. This agenda cannot be set until landowners are able to articulate to each other the value of their grassland, the risk of eastern redcedar encroachment, and some level of compatibility of agricultural production with prairie restoration goals.
A change in attitude among agricultural landowners about grazing management, particularly the need to moderate stocking rates, will be required before prescribed burning can be used to effectively control encroachment of eastern redcedar. In spite of an overall recognition of eastern redcedar encroachment, landowners do not associate prescribed burning with eastern redcedar control. Almost half the respondents support the idea of a burn cooperative; however, they lack the social infrastructure, tools, and experience needed to conduct prescribed burns. Taylor (2005) finds that prescribed burn cooperatives are sources of rancher empowerment, providing both confidence and experience as well as equipping them to mange rangelands better. Prior research on farmer-led groups that manage lands in agricultural watersheds for production and water quality goals have demonstrated success in addressing environmental concerns (Morton 2008). An intervention strategy we think has strong potential is the formation of a core group of landowners who have a vision for the grasslands and a willingness to be catalysts for change on the landscape, including developing a burn cooperative. This group effect can help frame the ecosystem and conservation message to landowners in ways that harmonize agricultural production conservation goals (Raedeke et al. 2001; Olenick et al. 2005), such as reducing soil erosion and invasive species control (i.e., weeds), with other conservation goals, such as prairie restoration and increasing biodiversity.

\section{LITERATURE CITED}

Anderson, W. P. 1996. Weed science principles. St. Paul, MN, USA: West Publishing. 598 p.

ANDERSON-WILK, M. 2008. Science and stewardship in a nonmonolithic conservation movement: facilitating positive change. Journal of Soil and Water Conservation 63(5):142A-146A.

Ansley, J. R., And G. A. Rasmussen. 2005. Managing native invasive juniper species using fire. Weed Technology 19:517-522.

Arbuckle, J. G., JR., P. Lasley, P. Konsching, and C. Kast. 2009. Summary report Iowa farm and rural life poll. Ames, IA, USA: Iowa State University Extension. PM 2093, December. 16 p.

BATIE, S. 2009. Green payments and the US Farm Bill: information and policy challenges. Frontier Ecology \& Environment 7:380-388.

Bidwell, T. G., J. R. Weir, R. E. Masters, and J. D. Carlson. 2006. Fire prescriptions for maintenance and restoration of native plant communities. Stillwater, OK, USA: Division of Agricultural Sciences and Natural Resources, Oklahoma Cooperative Extension Service. Report F-2878. 8 p.

Briggs, J. M., A. K. Knapp, J. M. Blair, J. L. Heisler, G. A. Hoch, M. S. Lett, and J. K. McCarron. 2005. An ecosystem in transition: causes and consequences of the conversion of mesic grassland to shrubland. BioScience 55:243-254.

Briggs, J. M., A. K. Knapp, and B. L. Brock. 2002. Expansion of woody plant in tallgrass prairie: a fifteen-year study of fire and fire-grazing interactions. The American Midland Naturalist 147:287-294.

Brunson, M. W., And J. Evans. 2005. Badly burned? Effects of an escaped prescribed burn on social acceptability of wildland fuels treatments. Journal of Forestry 103:134-138.

BRunson, M., AND B. Shindler. 2004. Geographic variation in social acceptability of wildland fuels management in the western United States. Society and Natural Resources 17:661-678.

Cleaveland, J. E., and D. N. Duvick. 1992. Iowa climate reconstructed from tree rings, 1640-1982. Water Resources Research 28:2607-2615.

Coppedge, B. R., D. M. Engle, S. D. Fuhlendorf, R. E. Masters, and M. S. Gregory. 2002. Landscape cover type and pattern dynamics in fragmented southern Great Plains grasslands, USA. Landscape Ecology 16:677-690. 
CuRTIN, C. 2007. Integrating landscape and ecosystems approaches through science-based collaborative conservation. Conservation Biology 21:4: 1117-1119.

Dillman, D. A. 2000. Mail and internet surveys: the tailored design method. New York, NY, USA: John Wiley and Sons. $464 \mathrm{p}$.

Edwards, C. A. 1989. The importance of integration in sustainable agriculture systems. Agriculture, Ecosystems and Environment 27:25-35.

Engle, D. M., and T. G. Bidwell. 2000. Plains grasslands. In: R. Jemison and C. Raish [EDS.]. Livestock management in the American Southwest: ecology, society, and economics. Amsterdam, Netherlands: Elsevier Science. p. 97-152.

Engle, D. M., B. R. Coppedge, and S. D. Funlendorf. 2008. From the dust bowl to the green glacier: human activity and environmental change in Great Plains grasslands. In: 0. Van Auken [ED.]. Western North American Juniperus communities. New York, NY, USA: Springer. p. 253-271.

Engle, D. M., AND J. F. Stritzke. 1992. Enhancing control of eastern redcedar through individual plant ignition following prescribed burning. Journal of Range Management 45:493-495.

Fargione, J. E., T. R. Cooper, D. J. Flaspohler, J. Hill, C. Lehman, T. McCoy, S. Mcleod, E. J. Nelson, K. S. Oberhauser, and D. Tilman. 2009. Bioenergy and wildlife: threats and opportunities for grassland conservation. BioScience 59:767-777.

Higgins, K. F., A. D. KRUSE, and J. L. PieHL. 1989. Prescribed burning guidelines in the northern Great Plains. Brookings, SD, USA: US Fish and Wildlife Service, Cooperative Extension Service, South Dakota State University. US Department of Agriculture EC 760.36 p.

KLINE, B. 2007. First along the river: a brief history of U.S. environmental movement. New York, NY, USA: Rowman \& Littlefield. $198 \mathrm{p}$.

Koontz, T. M. 2001. Money talks-but to whom? Financial versus nonmonetary motivations in land use decisions. Society and Natural Resources 14:51-65.

KreUter, U., M. TAYs, AND J. R. Conner. 2004. Landowner willingness to participate in a Texas brush reduction program. Journal of Range Management 57:230-237.

Kreuter, U. P., J. B. Woodard, C. A. Taylor, and W. R. Teague. 2008. Perceptions of Texas landowners regarding fire and its use. Rangeland Ecology \& Management 61:456-464.

Milleer, A. J., D. B. Faulkner, R. K. Knipe, D. F. Parrett, L. L. Berger, and D. R. Stronbehn. 2001. Critical control points for profitability in the cow-calf enterprise. Ames, IA, USA: Iowa State University. A.S. Leaflet R1750. 2001 Beef Research Report. 10 p.

Missouri Department of Conservation. 2005. Grand River Grasslands conservation opportunity area. Jefferson City, MO, USA: Conservation Commission of the State of Missouri. $6 \mathrm{p}$.

Moore, R. H., J. S. Parker, and M. Weaver. 2008. Agricultural sustainability, water pollution, and governmental regulations: lessons from the Sugar Creek farmers in Ohio. Culture \& Agriculture 30:1:3-16.

Morton, L. W. 2008. The role of civic structure in achieving performance based watershed management. Society \& Natural Resources 21:751-766.

Olenick, K. L., U. P. Kreuter, and J. R. Conner. 2005. Texas landowner perceptions regarding ecosystem services and cost-sharing land management programs. Ecological Economics 53:247-260.
Ortmann, J., J. Stubbendeck, R. A. Masters, G. H. Pfeiffer, and T. B. Bragg. 1998. Efficacy and costs of controlling eastern redcedar. Journal of Range Management 51:158-163.

Pimentel, D., L. Lach, R. Zuniaa, and D. Morrison. 2000. Environmental and economic costs of nonindigenous species in the United States. BioScience 50:53-65.

Raedeke, A. H., C. H. Nilon, and J. S. Rikoon. 2001. Factors affecting landowner participation in ecosystem management: a case study in south-central Missouri. Wildlife Society Bulletin 29:1:195-206.

Rossi, P. H., J. D. Wright, And A. B. Anderson. 1983. Handbook of survey research. San Diego, CA, USA: Academic Press.

Sabatier, P. A., C. Weible, And J. FiCker. 2005. Eras of water management in the United States: implications for collaborative watershed approaches. In: P. A. Sabatier, W. Focht, M. Lubell, Z. Trachtenberg, A. Vedlitz, and M. Matlock [EDs.]. Swimming upstream. Cambridge, MA, USA: MIT Press. p. 23-52.

Skinner, K., L. Smith, ANd P. Rice. 2000. Using noxious weed lists to prioritize targets for developing weed management strategies. Weed Science 48:640-644.

Stephens, S. E., J. A. Walker, D. R. Blunck, A. Jayaraman, D. E. Naugle, J. K. Ringelman, and A. J. Smith. 2008. Predicting risk of habitat conversion in native temperate grasslands. Conservation Biology 22:1320-1330.

TAYLOR, C. A. 2005. Prescribed burning cooperatives: empowering and equipping ranchers to manage rangelands. Rangelands 27:18-23.

The Nature Conservancy. 2008a. Draft Grand River Grasslands conservation action plan. St. Louis, MO, USA: The Nature Conservancy. 25 p.

The Nature Conservancy. 2008b. Grand River Grasslands, Dunn Ranch, \& Pawnee Prairie. Available at: http://www.nature.org/wherewework/northamerica/ states/missouri/preserves/art447.htm. Accessed 24 October 2008.

Triplett, G. B., AND W. A. Dick. 2008. No-tillage crop production: a revolution in agriculture! Agronomy Journal 100:S153-S165.

WaLKER, B., AND D. Salt. 2006. Resilience thinking: sustaining ecosystems and people in a changing world. Washington, DC, USA: Island Press. $174 \mathrm{p}$.

WALKER, D. J. 1982. A damage function to evaluate erosion control economics. American Journal of Agricultural Economics 64:690-698.

WeIR, J. R., AND T. G. Bidwell. 2005. Prescribed fire associations. Stillwater, OK, USA: Division of Agricultural Sciences and Natural Resources, Oklahoma Cooperative Extension Service. Report F-2880. 2 p

Wood, B. D., AND A. Doan. 2003. The politics of problem definition: applying and testing threshold models. American Journal of Political Science 47:640-653.

Woodhouse, C. A., AND J. T. OverpeCK. 1998. 2000 years of drought variability in the central United States. Bulletin of the American Meteorological Society 79:2693-2714.

Wulfhorst, J. D., N. Rimbey, And T. Darden. 2006. Sharing the rangelands, competing for a sense of place. American Behavioral Scientist 50:166-186.

YODER, J. 2008. Liability, regulation, and endogenous risk: the incidence and severity of escaped prescribed fires in the United States. Journal of Law \& Economics 51:294-325.

Yoder, J., D. Engle, and S. Fuhlendorf. 2004. Liability, incentives, and prescribed fire for ecosystem management. Frontiers in Ecology and the Environment 2:361-366.

ZOHRER, J. J. 2005. Securing a future for fish and wildlife: a conservation legacy for Iowans. Des Moines, IA, USA: Iowa Department of Natural Resources. 344 p. 